\title{
A first approach to the impact of the real exchange rate on industrial sectors in Colombia
}

\author{
Lya Paola Sierra and Karina Manrique L.
}

ABSTRACT

Much has been said about possible symptoms of Dutch disease in Colombia in the wake of a marked upsurge in commodity prices and the significant real appreciation of the national currency. This paper examines whether the real effective exchange rate had an impact on industry during the period 2000-2010. Specifically, it evaluates the effect of the appreciation of the real exchange rate on the value added of 63 industrial sectors in Colombia using the Arellano and Bond (1991) generalized method of moments (GMM) estimator. Overall, our results confirm a negative relationship between real exchange rate appreciation and industry. The analysis showed that real exchange rate appreciation had a significant impact on the value added of 21 sectors: a negative effect for 18 sectors and a positive effect for 3 sectors. data, Colombia University in Cali, Colombia. lyap@javerianacali.edu.co

Karina Manrique L. is a Professor with the industrial engineering curriculum project at the Francisco José de Caldas District University in Bogota, Colombia. kmanriquel@udistrital.edu.co 


\section{I}

\section{Introduction}

In 2003, the Colombian currency began one of the most marked periods of real appreciation in the country's recent history. Apart from the decrease recorded during one year owing to the global financial crisis, the real exchange rate appreciated by $51 \%$ in the period 2003-2011. This is the seventh highest rate of real appreciation out of a group of 95 countries, according to a World Bank index of real exchange rates.

One factor that contributed to the appreciation was the dramatic increase in oil prices during the period. Since oil makes up about half of the country's total exports, the $275 \%$ rise in real oil prices resulted in windfall profits and pushed up the nominal exchange rate.

The real exchange rate can influence the competitiveness of industrial products in international markets. As the Colombian peso appreciates in real terms it drives up the prices of local goods with respect to those from the rest of the world. This makes Colombian products less competitive than their overseas competitors and may have a negative impact on output and employment in sectors that produce tradable goods. In response to this problem, newspapers and journals, encouraged by the industrial sector, have recently issued warnings about the possible contagion of the Dutch disease in Colombia. The possible effects on manufacturing of this real appreciation of the exchange rate in Colombia have motivated this research, which sets out to determine the effect of the real exchange rate on industrial value added for the period 2000-2010.

We used data for 63 sectors from the Annual Manufacturing Survey, along with macroeconomic data, to conduct estimations using the Arellano and Bond (1991) generalized method of moments (GMM) estimator. We used cross-departmental, cross-sectoral information to evaluate the impact of real appreciation on each of the industrial sectors in Colombia.

The rest of the paper is organized as follows: in the next section, we briefly review the relevant literature; in section III we review the data and the econometric approach used in the study; in section IV we present the results of the model; and lastly, conclusions are drawn in section $\mathrm{V}$.

\section{II}

\section{Literature review}

The real appreciation of the peso against the dollar since 2003 (see figure 1) has raised fears among politicians and the industrial sector of de-industrialization in Colombia. As the period of appreciation coincided with the great upsurge in real oil prices (see figure 2) - a major export for Colombia - national newspapers started to debate whether Colombia was already suffering from symptoms of Dutch disease. ${ }^{1}$ Many economic analysts have written columns on this subject and the President of Colombia even made a reference to the topic in a

Lya Paola Sierra gratefully acknowledges the financial support received from the Pontifical Javeriana University in Cali.

${ }^{1}$ Other possible causes of the real appreciation of the exchange rate could have included the positive trends in foreign direct investment, the increased privatization of State agencies and, externally, excess liquidity in the United States and Europe. keynote speech given at the headquarters of the Economic Commission for Latin America and the Caribbean (ECLAC) in Chile:

"We are trying to attract investors to sectors other than oil and mining because we are now facing a prelude to the Dutch disease owing to the concentration of investment in these sectors."

President Juan Manuel Santos, 17 August 2011.

However, despite the media interest in the subject, few articles have been written on the possible symptoms of Dutch disease caused by the recent real appreciation of the currency in Colombia.

Dutch disease refers to the fallout caused by windfall profits from a resource discovery (Corden and Neary, 1982; Corden, 1984; Beverelli, Dell'Erba and Rocha, 2011), a resource price boom (Egert and Leonard, 2008; Algieri, 2011; Poncela, Senra and Sierra, 2012), an 
FIGURE 1

Colombia: real effective exchange rate index, 1990-2011

(Index $2005=100)$

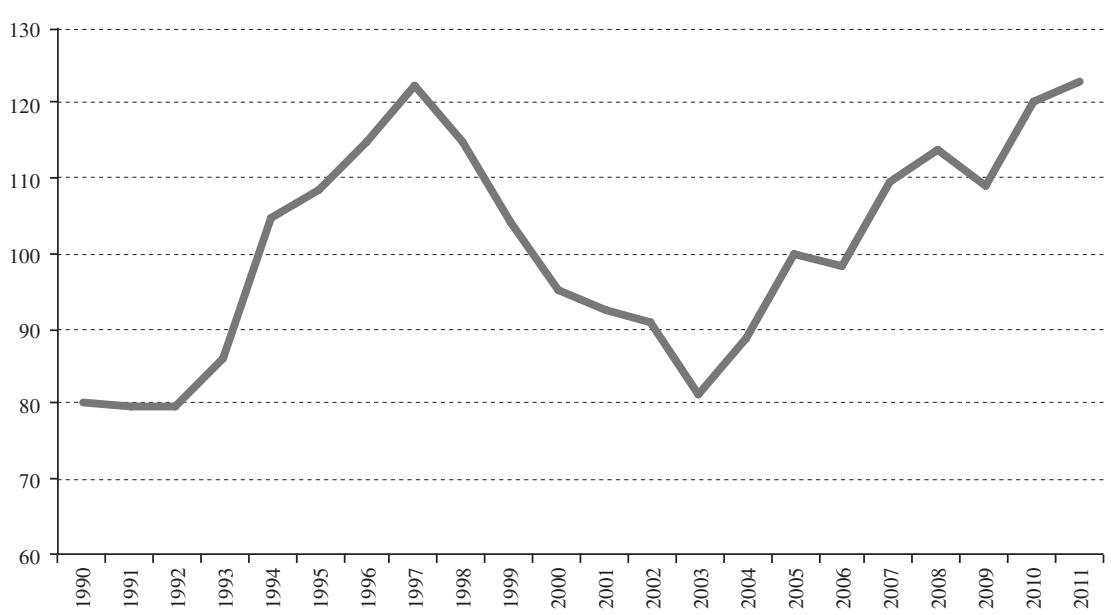

Source: World Bank.

FIGURE 2

Annual average Brent crude oil spot prices, 1990-2010

(Dollars per barrel)

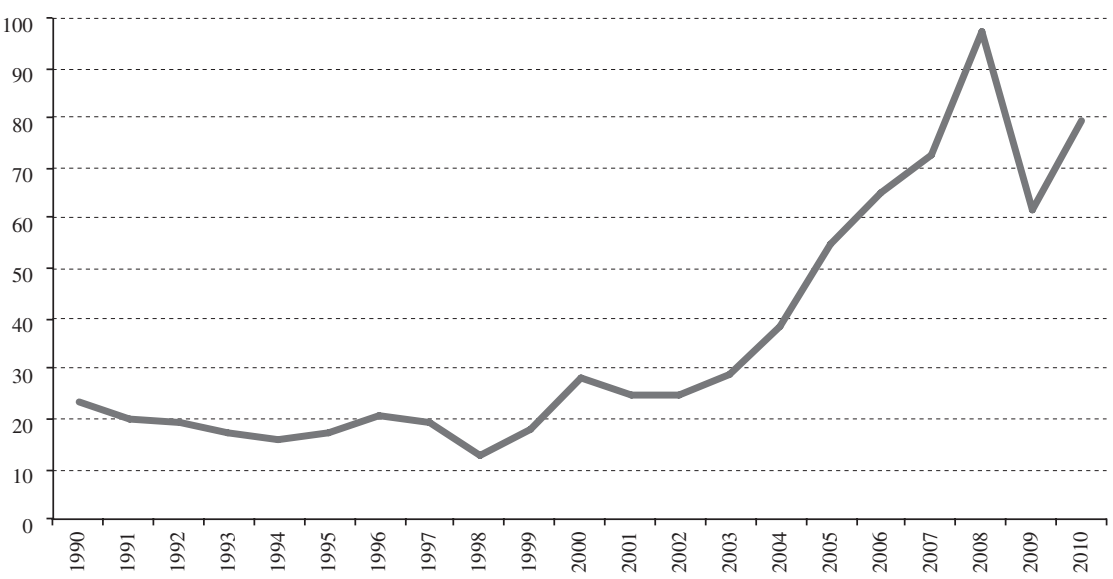

Source: Energy Information Administration.

upsurge in remittances (Acosta, Lartey and Mandelman, 2009; Guha, 2013) or higher capital inflows in the form of foreign aid or foreign direct investment (Lartey, 2011; Arellano and others, 2005; Prati and Tressel, 2005). ${ }^{2}$ The term "Dutch disease" is attributed to an article in

${ }^{2}$ Buiter and Purvis (1983) examine the relative importance of different shocks as causes of de-industrialization, by looking at the impact on the real exchange rate of factors including higher oil prices, a domestic oil discovery and monetary disinflation.
The Economist in 1977, which described the detrimental impact on the industrial sector in the Netherlands following the discovery of major gas deposits in the North Sea. Corden and Neary (1982) formulated the core theoretical model of Dutch disease. They used a Salter-Swan framework (Salter, 1959; Swan, 1960) to describe how windfall profits in a country can cause real appreciation followed by reductions in competitiveness and output in the non-resource tradable sector. A resource boom may lead to a real appreciation through two channels. First, 
newfound wealth can lead to higher rates of national absorption, through spending either by the government or directly by the owners of the factors. This increase in demand drives up the prices of non-tradable goods, forcing real appreciation. Second, the nominal exchange rate can appreciate in a flexible exchange rate regime owing to burgeoning inflows to the country. Given the traditional real exchange rate equation (see equation (1)), where the real exchange rate $(Q)$ is represented in the equation as the price of domestic goods $(\mathrm{P})$ relative to those from abroad $\left(\mathrm{P}^{*}\right)$ adjusted by the nominal exchange rate $(\mathrm{S})$, both forces lead to real exchange rate appreciation. Corden and Neary (1982) referred to this as the "spending effect".

$$
Q=S * \frac{P}{P^{*}}
$$

Taking logs, the real exchange rate is also denoted as:

$$
q_{t}=s_{t}+p_{t}-p_{t}^{*}
$$

Here, $s_{t}$ is the log of the foreign currency price of domestic currency (United States dollars per Colombian peso), $p_{t}$ and $p_{t}^{*}$ are the logs of the national and foreign country price indices, respectively. In this definition of the real exchange rate, an increase in $q_{t}$ means a real appreciation of the local currency and a decrease in $q_{t}$ reflects a real depreciation.

Apart from the "spending effect", Corden and Neary (1982) describe a "resource movement effect", referring to the reallocation of factors, especially labour, from the manufacturing sector to the booming resource sector. The reduction of labour in the manufacturing sector contributes to the de-industrialization process.

The literature seems to point to a clear causal link between a resource boom and a real appreciation of the national currency. However, the subsequent link between real appreciation and relative de-industrialization remains unclear (see Magud and Sosa (2010) for a judicious review of the literature on Dutch disease). In fact, a theoretical article by Buiter and Purvis (1983) posits that a resource boom might have a positive effect on manufacturing on the basis of the coexistence of real appreciation and an upsurge in growth. Manufacturing is thus contemporaneously influenced by appreciation, which shrinks international competitiveness, and local demand for manufacturing, which pushes up sales. Since Colombia, which is a small economy, takes the world price of manufactures as a constant, manufacturing output could be maintained through the higher domestic demand associated with the resource boom. That is, losses in competitiveness would be compensated by gains in domestic demand.

Moreover, real appreciation can potentially increase competitive pressures and force industrial restructuring, which can in turn boost productivity. The effect of the real exchange rate on manufacturing output depends on the exposure of industries to international markets. Industries that export most of their output, for example, might see their profits fall as they lose competitiveness in periods of real appreciation. Whereas industries that import most of their intermediate inputs could benefit from local currency appreciation, since real appreciation tends to make these inputs cheaper. To summarize, a real appreciation shock has an ambiguous effect on profitability and industrial performance. Some of the papers that examine the real exchange rate and industrial performance include Burgess and Knetter (1998); Campa and Goldberg (1995 and 2001); Goldberg, Tracy and Aaronson (1999); Goldberg (1993); Campbell and Lapham (2004); Ekholm, Moxnes and Ulltveit-Moe (2012), and Berman, Martin and Mayer (2012).

Although the relationship between the real exchange rate and industrial output remains unclear, there appears to be strongly supported cross-country statistical evidence that overvalued currencies are associated with slow growth, especially in less developed countries (Rajan and Subramanian, 2011; Rodrik, 2008, and Berg, Ostry and Zettelmeyer, 2012). Tradable sectors, particularly those in manufacturing, seem to be the link between the real exchange rate and economic growth. Rodrik (2008), for example, shows that the bigger a tradable industrial sector is in a less developed country, the more overvaluation hurts growth.

In the case of Colombia, there are few articles that examine the real exchange rate in relation to manufacturing performance. The article bearing the closest resemblance to this study is Echavarría and Arbeláez (2003), who measured the effect of the exchange rate on investment, sales and profits in Colombian companies in 1994-2002. Unlike our article, however, Echavarría and Arbeláez (2003) took into account a devaluation period in a firm-level analysis, which included only manufacturing firms. Carranza and Moreno (2013) analysed the vertical industrial chain of Colombia for the period 1990-2010, evaluating possible industrialization, but did not specifically assess the effect of the exchange rate on industry. Other studies addressing the subject include Clavijo (1990), which evaluated the effect of the real exchange rate on 
productivity, and Rhenals and Saldarriaga (2007), which explored the relationship between the real exchange rate and Colombia's economic growth. In this paper we concentrate exclusively on the effects of the Colombian real exchange rate on manufacturing value added. Further research should be carried out to evaluate the potential impact of a resource boom on economic growth in Colombia.

\section{III}

\section{Econometric approach and data}

\section{Data}

We used annual data from the Annual Manufacturing Survey conducted by the National Administrative Department of Statistics (DANE) of Colombia. The survey contains information on 63 industrial sectors in 23 departments (geographical areas) in Colombia from 2000 to 2010. The names of the sectors are listed in annex 1. We used variables from the Annual Manufacturing Survey such as employment, number of firms per industry and wages paid to personnel.

In addition, we used data on macroeconomic variables such as the real effective exchange rate from the International Monetary Fund, the per capita income for each department from DANE and the lending rate from the central bank of Colombia. We constructed the ratio of imported intermediate goods, which takes into account the ratio of industrial intermediate imports to total intermediate goods, with a view to controlling for each industry's openness to foreign markets. ${ }^{3}$

As a first look at the evolution of the sectors from 2000 to 2010, we grouped the data using the two-digit numerical codes of the International Standard Industrial Classification of All Economic Activities (ISIC) adapted for Colombia by DANE (see annex 2). According to this information, the sector with the greatest value added in 2000 was the manufacture of food products and beverages, followed by the manufacture of chemicals and chemical products; the manufacture of coke, refined petroleum products and nuclear fuel; the manufacture of furniture; and the manufacture of other non-metallic mineral products. From 2000 to 2010, the top two sectors, food and chemicals, saw their share in the total value added slide from $28 \%$ to $27 \%$ and from $16 \%$ to $14 \%$, respectively. Likewise, the contribution to total value added of the manufacture of other non-metallic mineral

\footnotetext{
${ }^{3}$ All data have been log-transformed.
}

products contracted from $7.5 \%$ to $7.2 \%$. By contrast, the manufacture of furniture and the manufacture of coke and refined petroleum products increased their share in total value added between 2000 and 2010. The furniture sector accounted for $7.7 \%$ of total value added in 2000 , increasing to $8.7 \%$ in 2010 , and the manufacture of coke and refined petroleum products saw the largest increase in the whole sample of sectors, from $7.9 \%$ to $12.8 \%$.

As we can see from this information, industrial value added is concentrated in a small number of sectors in Colombia. The top five sectors accounted for $67 \%$ of total value added in 2000, and by 2010 their share had risen to $70 \%$.

\section{The model}

We propose the following model:

$$
\begin{aligned}
& y_{d s t}=\beta_{0}+\beta_{1} w_{d s t}+\beta_{2} i_{t}+\beta_{3} q_{t}+\beta_{4} I I R_{d s t}+\varepsilon_{i t} \\
& y_{d s t}=\alpha_{0}+\beta_{2} q_{t} D_{s}+\beta_{3} r g d p_{d t}+\beta_{2} i_{t} \\
& +\beta_{4} w_{d s t}+\beta_{6} I I R_{d s t}+\varepsilon_{i t}
\end{aligned}
$$

The variable $y$ represents the value added of industrial sector $s$ in department $d$, in year $t$. The real exchange rate is represented by the variable $q_{t}$ and $D_{s}$ is a dummy per industry. The rest of the variables are: real per capita income for each department, $r g d p_{d t}$, real wage per industry $w_{d s t}$, real interest rate, $i_{t}$, and the variable $I I R_{d s t}$ representing the intermediate input ratio. In equation (3) we aim to measure the overall impact of the real exchange rate on the industry in general. The marginal effect of fluctuations in the real effective exchange rate, whether real appreciation or depreciation, on each industry is captured by parameter $\beta_{2}$ in equation (4). 
We are aware of some known identification problems regarding the estimation, such as the multi-causality of industrial value added and the real exchange rate, as well as the possibility of multicollinearity between dependent variables. In order to address these problems, we estimated a dynamic linear panel data model, using the ArellanoBond GMM estimator. The advantage of this model is that it relaxes the strong exogeneity assumption, allowing the explanatory variables to be correlated with the error term. The strategy is to use the lags of the variables as instruments. A brief analysis of the characteristics and assumptions of this model is shown below.

Consider a model that includes the lag of the dependent variable, $Y_{i t}$ as a regressor (the dynamics introduced in the model are given by this feature). The basic dynamic autoregressive model panel data can be represented as follows:

$$
Y_{i t}=\alpha Y_{i, t-1}+X_{i t}^{\prime} \beta+\eta_{i}+u_{i t}
$$

where $\mathrm{t}=1, \ldots, \mathrm{T}$.

$X_{i t}^{\prime}$ is the row vector of observed explanatory variables for individual $i$ at time $t ; \beta$ is the vector of parameters to be estimated; $\eta_{i}$ represents the time invariant individual effect and $u_{i t}$, represents the idiosyncratic errors.
In equation (5), as in equations (3) and (4), lags of the dependent variable are taken as explanatory variables. This fact introduces bias to the estimation by ordinary least squares (OLS), since these violate the strict exogeneity assumption. To tackle this issue Anderson and Hsiao (1981) and Arellano and Bond (1991) suggested differencing the model and then using instrumental variables estimations.

$$
\Delta Y_{i t}=\alpha \Delta Y_{i, t-1}+\Delta X_{i t}^{\prime} \beta+\Delta v_{i t}
$$

By transforming the regressors by first-differencing, as shown in equation (6), the fixed specific effect, $\eta_{i}$, is removed, because it does not vary with time. We follow Arellano and Bond (1991) and use the GMM estimator, which takes into account the passing information from $Y$ and $X$ as instruments.

As a robustness check, we also estimated the Arellano and Bover (1995) system GMM estimator. According to these authors, if the autoregressive process is persistent, or when $\mathrm{T}$ (number of years) is small, then the lagged levels are weak instruments. They proposed using additional moment conditions in which lagged differences of the dependent variable are orthogonal to levels of the disturbances.

\section{IV}

\section{Estimation results}

Before looking at the results disaggregated by industrial sector, we first show the results for equation (3), which give an initial overview of the effect of the real exchange rate on industry. 4

We obtained estimates of equation (3). We report the results for the two-step GMM estimator for both the first-differenced equation and the system equation. We take as instruments the lagged levels dated $t-2$ and earlier. As additional instruments, we take the lagged differences dated $t-1$. The estimation results are reported in annex 3. Annex table A.3.1 provides estimates for equation (3) using the first-differences GMM and the system GMM estimator. The results in column (2) are controlled

\footnotetext{
${ }^{4}$ In this section we refer to the sectors listed in table A.1.1 of annex 1, disaggregated at the three-digit level of the International Standard Industrial Classification of All Economic Activities (ISIC), Rev. 3, adapted for Colombia by DANE.
}

for departmental per capita income, whereas those in column (1) are not. The lower part of table A.3.1 includes the results of the Sargan test and Arellano-Bond test used to evaluate the overidentifying conditions and the serial correlation in the first-differenced disturbances.

The results show that fluctuations in the real exchange rate significantly affect the industrial sector in general. In fact, a $1 \%$ appreciation of the real exchange rate produces a $0.29 \%$ decrease in value added, ceteris paribus, in both the first-differences and system GMM estimations. The real appreciation of the Colombian peso creates a loss of competiveness in international markets since local prices are higher than those of international competitors. Also, domestic consumers replace expensive national goods with cheaper imports.

When departmental per capita income is controlled for, the results of the estimations for equation (3) show that the real exchange rate has slightly less of an 
impact on the value added of the industrial sector. An appreciation of $1 \%$ generates a reduction in the value added of $0.26 \%$ in both the first-differences and system GMM estimations (columns numbered (2) in table A.3.1). Interestingly, even though there is a negative effect of an appreciation in the same year, we found that industrial value added is affected significantly and in a positive way by the lag of the real exchange rate.

With respect to the results disaggregated by industrial sector corresponding to equation (4), as with previous estimations, we report results for the two-step GMM estimator for the first-differenced equation, using as instruments the lagged levels dated $t-2$ and earlier. We evaluated two models: the first (in column (1) in table A.3.2) does not take into account the variable of departmental per capita income, while the second model (in column (2)) does control for the $r g d p_{t}$ variable. ${ }^{5}$

We found that the real effective exchange rate had significant marginal effects in 21 industries. Real appreciation generated a reduction in the value added of 18 of those industries. The manufacturing sectors that were hit hardest were: television and radio receivers, veneer sheets, finishing of textiles not produced in the same production unit, rubber products, non-metallic mineral products, and sugar mills and refineries. In contrast, appreciation generated positive effects in the value added of only three sectors: manufacture of optical instruments and photographic equipment, publishing and the manufacture of insulated wire and cable. Annex table A.3.3 contains a summary of the sectors that are significantly affected by fluctuations in the real exchange rate (only the sectors significantly affected by the variable $q_{t}$ in equation (4)).

It is striking that most of the sectors that are negatively influenced by the real exchange rate are those that account for the largest share in industrial value added. The exception is the manufacture of furniture, which is not significantly affected by real exchange rate fluctuations. Surprisingly, the value added of the manufacture of refined petroleum products has a negative relationship with $q_{t}$, that is, a real appreciation of $1 \%$ leads to a loss in the value added of this sector of about $1.13 \%$.

The specification tests do not produce evidence against any model. The Sargan test leads to non-rejection of the null hypothesis of that model and overidentifying conditions are correctly specified. Furthermore, the autocorrelation tests $\mathrm{c} 1$ and $\mathrm{c} 2$ (see notes to tables A.3.1 and A.3.2) are consistent with the structure that we proposed for the idiosyncratic error term.

\footnotetext{
${ }^{5}$ We also estimated the system GMM model in this equation, however, the Sargan statistic rejected the different models we proposed.
}

In sum, the 18 sectors that are hit by appreciation account for approximately $53 \%$ of total value added, on average, between 2000 and 2010. Conversely, the three sectors that benefit from appreciation represent $4 \%$ of total value added (see annex table A.3.4). Our results show, therefore, that real appreciation is detrimental to the sectors representing more than half of total manufacturing value added; however, for the 38 sectors that account for $44.8 \%$ of total manufacturing value added, the real exchange rate does not have a significant effect. This non-significance may have to do with the degree of openness of the Colombian economy: from 2000 to 2010 , trade accounted for a $35 \%$ share in total gross domestic product (GDP) on average. An appreciation of the real exchange rate erodes the competitiveness of domestic firms in the international market, which reduces net exports and shifts part of domestic demand from domestic goods to foreign goods. As a consequence, according to the Dutch disease hypothesis, this leads to a drop in production and employment. However, when the degree of openness of the economy is not large, as is the case in Colombia, these effects do not necessarily spread to all the manufacturing sectors. Moreover, for manufacturing, the domestic market is more important than the external market. For the period 2000-2009, for example, domestic sales represented about $83 \%$ of total manufacturing sales, according to DANE. A further avenue for research would be to evaluate the long-term impact of the real exchange rate on manufacturing as the country becomes increasingly open to trade. This paper should persuade policymakers to consider the possible impacts of real exchange rate fluctuations on manufacturing in an economy that is wide open to trade.

It is important to note that the share of manufacturing in GDP for the period 2000-2010 was only $15.4 \%$ on average, while services accounted for $59.3 \%$. Therefore, we cannot be conclusive about the effects of the real exchange rate on Colombia's GDP. In fact, as shown in figure 3 , there was a huge decline in the contribution of industry to Colombian GDP in the 1990s, coinciding with the introduction of trade liberalization policies. In our period of analysis, from 2000 to 2010, industry recovered to some extent. According to some authors, such as Echavarría and Villamizar (2006), the deindustrialization process in Colombia started in 1960, with the decrease in industry's share of employment, and in 1970, with the decrease in its share of overall production. Echavarría and Villamizar (2006), as well as Poncela, Senra and Sierra (2012), did not find evidence of de-industrialization related to Dutch disease in the long term. 
FIGURE 3

Colombia: share of services and industry in gross domestic product, 1965-2011 (Percentages)

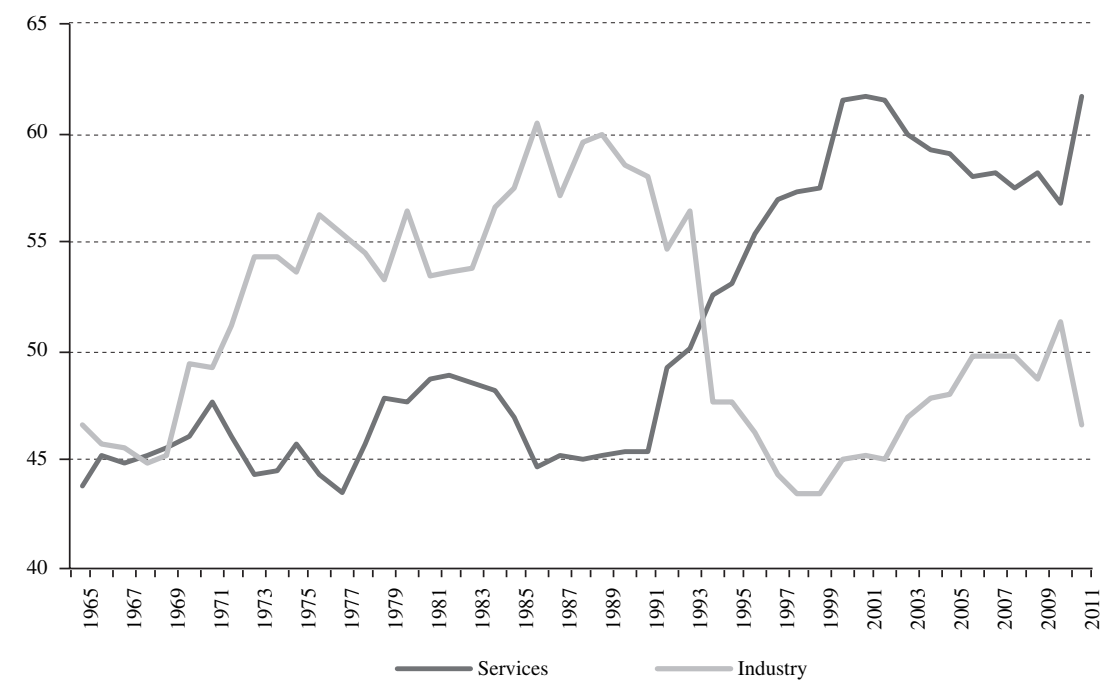

Source: Data Service \& Information, [online] http://www.dsidata.com/default/page/slug/about.

\section{Conclusions}

In view of the national interest in the possible impact on industry of real appreciation caused by the upsurge in oil prices after the year 2000, we sought to evaluate one of the symptoms of the Dutch disease by analysing the impact of the appreciation of the real effective exchange rate on the value added of 63 industrial sectors in Colombia during the period 2000-2010.

We used the annual panel data set of the Annual Manufacturing Survey carried out by DANE, and conducted estimations using the first-differenced GMM estimator of Arellano and Bond (1991).

Our results suggest that the real exchange rate had a significant impact on the industrial sector in general. We found that the effect was negative: that is, a $1 \%$ appreciation of the real exchange rate produced a decrease in industrial value added of between $0.26 \%$ and $0.29 \%$.

The estimation results for individual industrial sectors showed that real exchange rate appreciation had a negative impact on 18 sectors and a positive impact on 3 sectors. It is striking that the real exchange rate had no significant impact on most of the sectors (38) during the period 2000-2010. The sectors that were affected most markedly were those with a larger share in total industrial value added. Overall, the sectors that suffered as a result of the real appreciation of the Colombian peso accounted for $53 \%$ of total manufacturing value added, $39 \%$ of all manufacturing employees and $36 \%$ of firms in the manufacturing sectors.

The results in this paper provide initial insight into the effects of the real exchange rate on the industrial sectors in Colombia. Although this article cannot confirm an acceleration of the de-industrialization process in the period of study because a large number of sectors were not affected by the real exchange rate, it gives a list of sectors that are potentially sensitive to fluctuations in the real exchange rate. Government policy should focus special attention on these sectors, which are potentially harmed in periods of appreciation. Measures such as tax breaks or credit facilities could provide temporary relief to those sectors. Further research is needed to examine how the real exchange rate affects other important variables such as industrial employment, productivity and number of firms per sector in order to evaluate the total impact of the real exchange rate on manufacturing. 
ANNEX 1

Table A.1.1

Sectors included in the study

Sector

International Standard Industrial Classification of All Economic Activities (ISIC) Rev. 3 adapted for Colombia

$\begin{array}{lr}\text { Production, processing and preservation of meat and fish } & 151\end{array}$

Processing of fruits, vegetables, oils and fats 152

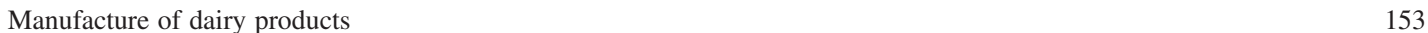

Production of grain mill products, starches and starch products, and prepared animal feeds 154

Manufacture of bakery products, macaroni, noodles, couscous and similar farinaceous products 155

Manufacture of coffee 156

$\begin{array}{lr}\text { Sugar mills and refineries } & 157\end{array}$

$\begin{array}{lr}\text { Manufacture of other food products } & 158\end{array}$

$\begin{array}{lr}\text { Manufacture of beverages } & 159\end{array}$

$\begin{array}{lr}\text { Manufacture of tobacco products } & 160\end{array}$

$\begin{array}{lr}\text { Preparation and spinning of textile fibres } & 171\end{array}$

$\begin{array}{lr}\text { Weaving of textiles } & 172\end{array}$

Finishing of textiles not produced in the same production unit 173

$\begin{array}{lr}\text { Manufacture of other textile products } & 174\end{array}$

$\begin{array}{lr}\text { Manufacture of knitted and crocheted fabrics and articles } & 175\end{array}$

$\begin{array}{lr}\text { Manufacture of wearing apparel, except fur apparel } & 181\end{array}$

$\begin{array}{lr}\text { Tanning and preparation of leather } & 191\end{array}$

$\begin{array}{lr}\text { Manufacture of footwear } & 192\end{array}$

$\begin{array}{lr}\text { Manufacture of travel goods, handbags and similar articles } & 193\end{array}$

Sawing, planing and impregnation of wood 201

Manufacture of veneer sheets, manufacture of plywood, laminboard, particle board 202

and other panels and boards

Manufacture of builders' carpentry and joinery 203

$\begin{array}{ll}\text { Manufacture of wooden containers } & 204\end{array}$

Manufacture of other products of wood, manufacture of articles of cork, straw and plaiting materials 209

$\begin{array}{lr}\text { Manufacture of paper, cardboard and paper and cardboard products } & 210\end{array}$

$\begin{array}{lr}\text { Publishing } & 221\end{array}$

$\begin{array}{lr}\text { Printing } & 222\end{array}$

$\begin{array}{lr}\text { Service activities related to printing } & 223\end{array}$

$\begin{array}{lr}\text { Manufacture of coke oven products } & 231\end{array}$

Manufacture of refined petroleum products $\quad 232$

$\begin{array}{lr}\text { Manufacture of basic chemicals } & 241\end{array}$

$\begin{array}{lr}\text { Manufacture of other chemical products } & 242\end{array}$

Manufacture of synthetic and artificial fibres $\quad 243$

$\begin{array}{lr}\text { Manufacture of rubber products } & 251\end{array}$

$\begin{array}{lr}\text { Manufacture of plastics products } & 252\end{array}$

Manufacture of glass and glass products $\quad 261$

$\begin{array}{lr}\text { Manufacture of non-metallic mineral products n.e.c. } & 269\end{array}$

$\begin{array}{lr}\text { Manufacture of basic iron and steel } & 271\end{array}$

$\begin{array}{lr}\text { Manufacture of basic precious and non-ferrous metals } & 272\end{array}$

Manufacture of structural metal products, tanks, reservoirs and steam generators 281

$\begin{array}{lr}\text { Manufacture of other fabricated metal products and related metalworking service activities } & 289\end{array}$

$\begin{array}{lr}\text { Manufacture of general purpose machinery } & 291\end{array}$

Manufacture of special purpose machinery $\quad 292$

Manufacture of domestic appliances n.e.c. $\quad 293$

$\begin{array}{lr}\text { Manufacture of office, accounting and computing machinery } & 300\end{array}$

$\begin{array}{ll}\text { Manufacture of electric motors, generators and transformers } & 311\end{array}$

Manufacture of electricity distribution and control apparatus $\quad 312$ 
Table A.1.1 (conclusion)

Sector

International Standard Industrial Classification of All Economic Activities (ISIC) Rev. 3 adapted for Colombia

Manufacture of insulated wire and cable 313

Manufacture of accumulators and electrical batteries

Manufacture of electric lamps and lighting equipment

Manufacture of other electrical equipment n.e.c.

Manufacture of electronic valves and tubes and other electronic components

Manufacture of television and radio receivers, sound or image recording or reproducing

apparatus, and associated goods

Manufacture of medical appliances and instruments and appliances for measuring,

checking, testing, navigating and other purposes, except optical instruments

Manufacture of optical instruments and photographic equipment

Manufacture of motor vehicles and their engines

Manufacture of bodies (coachwork) for motor vehicles; manufacture of trailers and semi-trailers $\quad 342$

Manufacture of parts and accessories (auto parts) for motor vehicles and their engines 343

$\begin{array}{ll}\text { Building and repairing of ships and boats } & 351\end{array}$

$\begin{array}{ll}\text { Manufacture of aircraft and spacecraft } & 353\end{array}$

$\begin{array}{ll}\text { Manufacture of other transport equipment n.e.c. } & 359\end{array}$

$\begin{array}{lr}\text { Manufacture of furniture } & 361\end{array}$

$\begin{array}{ll}\text { Manufacturing n.e.c. } & 369\end{array}$

Source: prepared by the authors, on the basis of the International Standard Industrial Classification of All Economic Activities (ISIC Rev. 3) adapted for Colombia, as included in the Annual Manufacturing Survey conducted by the National Administrative Department of Statistics (DANE) of Colombia.

n.e.c.: not elsewhere classified. 


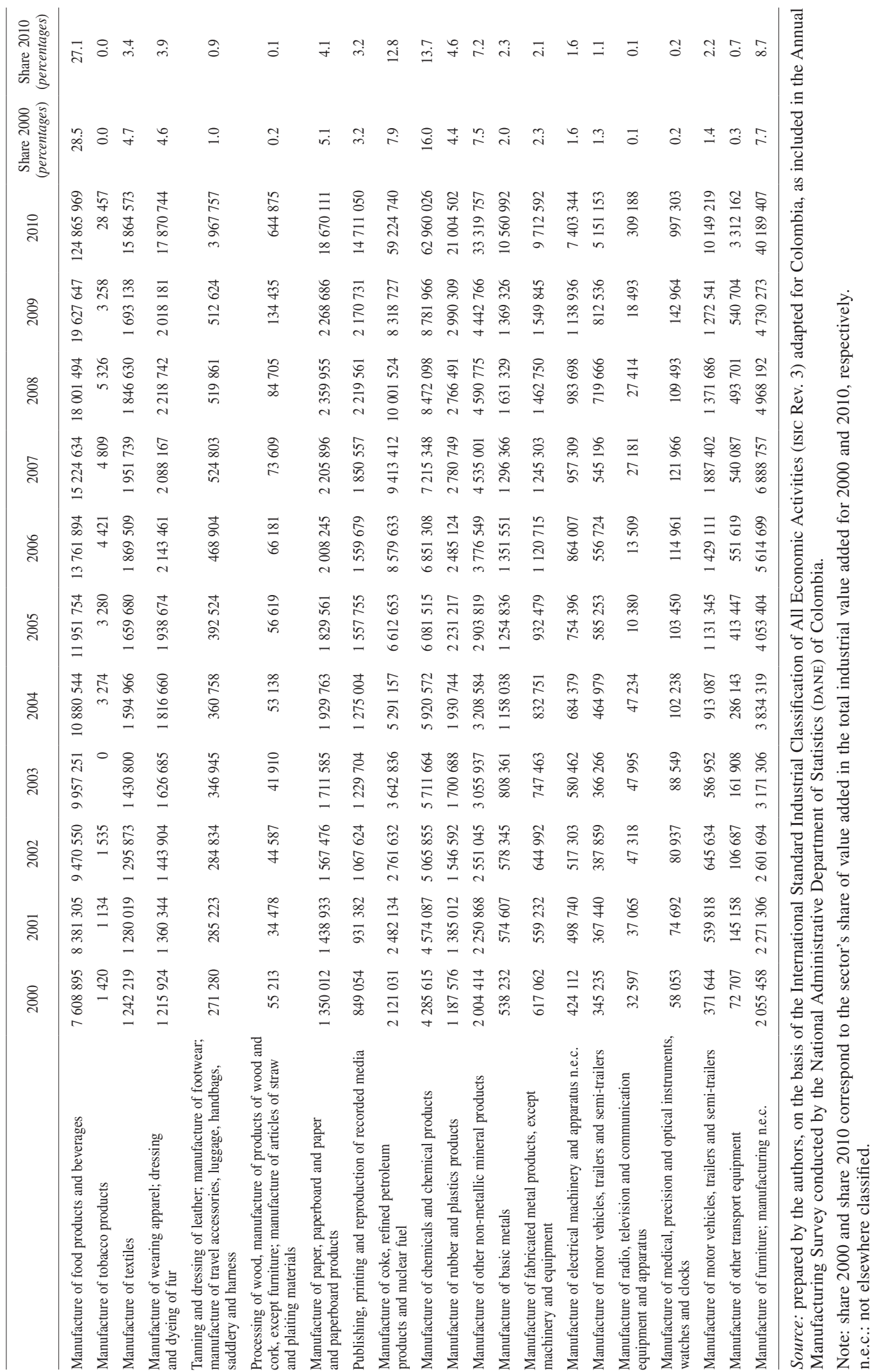


ANNEX 3

Estimation results

TABLE A.3.1

Colombia: estimation results for equation (3) showing the aggregate impact of the real effective exchange rate on industrial value added

\begin{tabular}{|c|c|c|c|c|}
\hline & \multicolumn{4}{|c|}{ Generalized method of moments (GMM) estimates } \\
\hline & \multicolumn{2}{|c|}{ First-differences } & \multicolumn{2}{|c|}{ System } \\
\hline & (1) & (2) & (1) & $(2)$ \\
\hline$y_{t-1}$ & $\begin{array}{c}0.603 \\
(0.055)^{\mathrm{a}}\end{array}$ & $\begin{array}{c}0.689 \\
(0.062)^{\mathrm{a}}\end{array}$ & $\begin{array}{c}0.615 \\
(0.040)^{\mathrm{a}}\end{array}$ & $\begin{array}{c}0.658 \\
(0.038)^{\mathrm{a}}\end{array}$ \\
\hline$y_{t-2}$ & $\begin{array}{c}0.023 \\
(0.019)\end{array}$ & $\begin{array}{c}0.047 \\
(0.023)^{\mathrm{b}}\end{array}$ & $\begin{array}{c}0.029 \\
(0.017)\end{array}$ & $\begin{array}{l}0.049 \\
(0.020)^{\mathrm{b}}\end{array}$ \\
\hline$w_{t}$ & $\begin{array}{l}0.732 \\
(0.043)^{\mathrm{a}}\end{array}$ & $\begin{array}{c}0.758 \\
(0.047)^{\mathrm{a}}\end{array}$ & $\begin{array}{c}0.727 \\
(0.041)^{\mathrm{a}}\end{array}$ & $\begin{array}{l}0.744 \\
(0.045)^{\mathrm{a}}\end{array}$ \\
\hline$w_{t-1}$ & $\begin{array}{l}-0.402 \\
(0.063)^{\mathrm{a}}\end{array}$ & $\begin{array}{l}-0.439 \\
(0.067)^{\mathrm{a}}\end{array}$ & $\begin{array}{l}-0.39 \\
(0.051)^{\mathrm{a}}\end{array}$ & $\begin{array}{l}-0.395 \\
(0.050)^{\mathrm{a}}\end{array}$ \\
\hline$i_{t}$ & $\begin{array}{l}-0.102 \\
(0.038)^{b}\end{array}$ & $\begin{array}{l}-0.126 \\
(0.039)^{\mathrm{a}}\end{array}$ & $\begin{array}{l}-0.087 \\
(0.034)^{\mathrm{b}}\end{array}$ & $\begin{array}{l}-0.118 \\
(0.037)^{b}\end{array}$ \\
\hline$i_{t-1}$ & $\begin{array}{l}-0.295 \\
(0.056)^{\mathrm{a}}\end{array}$ & $\begin{array}{l}-0.361 \\
(0.060)^{\mathrm{a}}\end{array}$ & $\begin{array}{l}-0.286 \\
(0.052)^{\mathrm{a}}\end{array}$ & $\begin{array}{l}-0.360 \\
(0.061)^{\mathrm{a}}\end{array}$ \\
\hline$q_{t}$ & $\begin{array}{l}-0.297 \\
(0.087)^{b}\end{array}$ & $\begin{array}{l}-0.269 \\
(0.0893)^{\mathrm{a}}\end{array}$ & $\begin{array}{l}-0.297 \\
(0.084)^{\mathrm{a}}\end{array}$ & $\begin{array}{l}-0.261 \\
(0.088)^{b}\end{array}$ \\
\hline$q_{t-1}$ & $\begin{array}{l}0.05 \\
(0.067)\end{array}$ & $\begin{array}{l}0.165 \\
(0.081)^{\mathrm{b}}\end{array}$ & $\begin{array}{c}0.011 \\
(0.064)\end{array}$ & $\begin{array}{c}0.138 \\
(0.076)^{\mathrm{c}}\end{array}$ \\
\hline$I I T_{t}$ & $\begin{array}{l}-1.00 \mathrm{E}-08 \\
(6.49 \mathrm{E}-09)^{\mathrm{a}}\end{array}$ & $\begin{array}{l}-1.14 \mathrm{E}-08 \\
(6.71 \mathrm{E}-09)^{\mathrm{c}}\end{array}$ & $\begin{array}{l}-1.12 \mathrm{E}-08 \\
(0.00)^{\mathrm{a}}\end{array}$ & $\begin{array}{l}-1.11 \mathrm{E}-08 \\
(6.37 \mathrm{E}-09)^{\mathrm{c}}\end{array}$ \\
\hline$r g d p_{t}$ & & $\begin{array}{c}0.022 \\
(0.024)\end{array}$ & & $\begin{array}{l}0.02 \\
(0.023)\end{array}$ \\
\hline$r g d p_{t-1}$ & & $\begin{array}{l}-0.529 \\
(0.176)^{b}\end{array}$ & & $\begin{array}{l}-0.484 \\
(0.154)^{b}\end{array}$ \\
\hline cons & $\begin{array}{l}1.806 \\
(0.416)^{\mathrm{a}}\end{array}$ & $\begin{array}{c}7.084 \\
(1.786)^{\mathrm{a}}\end{array}$ & & $\begin{array}{c}6.565 \\
(1.622)^{\mathrm{a}}\end{array}$ \\
\hline Number of observations & 2906 & 2906 & 3355 & 3355 \\
\hline Observations per group (average) & 7.21 & 7.21 & 7.712 & 7.712 \\
\hline Sargan test $p$-value & 0.1404 & 0.380 & 0.3047 & 0.638 \\
\hline c1 ( $p$-value) & 0.000 & 0.000 & 0.000 & 0.000 \\
\hline c2 ( $p$-value) & 0.2184 & 0.354 & 0.2907 & 0.502 \\
\hline
\end{tabular}

Source: prepared by the authors.

${ }^{\mathrm{a}} \mathrm{p}<0.01$.

${ }^{\mathrm{b}} \mathrm{p}<0.05$

$\mathrm{c} \mathrm{p}<0.1$.

Note: standard errors in parentheses. Sargan test for overidentifying restrictions. c1 and c2 tests for first and second order correlation in first-differenced residuals. 
Colombia: estimation results for equation (4) showing the disaggregate impact of the real effective exchange rate on the industrial sectors

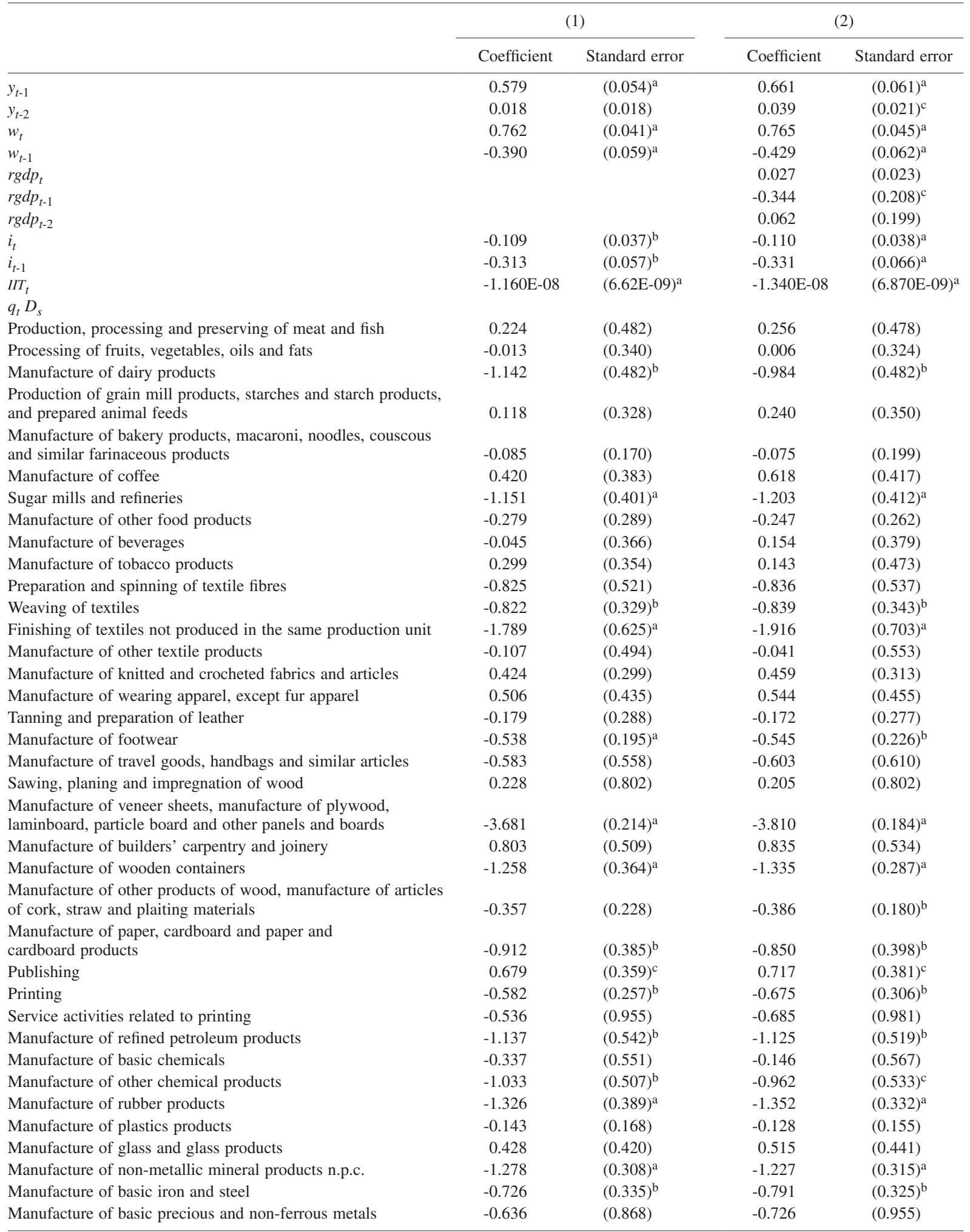


Table A.3.2 (conclusion)

\begin{tabular}{|c|c|c|c|c|}
\hline & \multicolumn{2}{|c|}{ (1) } & \multicolumn{2}{|c|}{$(2)$} \\
\hline & Coefficient & Standard error & Coefficient & Standard error \\
\hline $\begin{array}{l}\text { Manufacture of structural metal products, tanks, } \\
\text { reservoirs and steam generators }\end{array}$ & -0.770 & $(0.378)^{\mathrm{b}}$ & -0.819 & $(0.413)^{\mathrm{b}}$ \\
\hline $\begin{array}{l}\text { Manufacture of other fabricated metal products and related } \\
\text { metalworking service activities }\end{array}$ & -0.336 & $(0.382)$ & -0.348 & $(0.396)$ \\
\hline Manufacture of general purpose machinery & 0.529 & $(0.425)$ & 0.604 & $(0.428)$ \\
\hline Manufacture of special purpose machinery & 0.123 & $(0.285)$ & 0.175 & $(0.270)$ \\
\hline Manufacture of domestic appliances n.p.c. & 0.048 & $(0.506)$ & -0.010 & $(0.547)$ \\
\hline Manufacture of electric motors, generators and transformers & 0.218 & $(0.891)$ & 0.233 & $(0.944)$ \\
\hline Manufacture of electricity distribution and control apparatus & -0.588 & $(0.728)$ & -0.645 & $(0.748)$ \\
\hline Manufacture of insulated wire and cable & 2.953 & $(0.148)^{\mathrm{a}}$ & 3.013 & $(0.153)^{\mathrm{a}}$ \\
\hline Manufacture of accumulators and electrical batteries & 0.244 & $(0.561)$ & 0.330 & $(0.352)$ \\
\hline Manufacture of electric lamps and lighting equipment & -1.033 & $(0.310)^{\mathrm{a}}$ & -1.036 & $(0.340)^{\mathrm{a}}$ \\
\hline Manufacture of other electrical equipment n.p.c. & 0.398 & $(0.340)$ & 0.405 & $(0.262)$ \\
\hline $\begin{array}{l}\text { Manufacture of electronic valves and tubes and } \\
\text { other electronic components }\end{array}$ & 0.931 & $(0.615)$ & 0.996 & $(0.681)$ \\
\hline $\begin{array}{l}\text { Manufacture of television and radio receivers, sound or image } \\
\text { recording or reproducing apparatus, and associated goods }\end{array}$ & -4.076 & $(0.280)^{\mathrm{a}}$ & -3.831 & $(0.323)^{\mathrm{a}}$ \\
\hline $\begin{array}{l}\text { Manufacture of medical appliances and instruments and } \\
\text { appliances for measuring, checking, testing, navigating and } \\
\text { other purposes, except optical instruments }\end{array}$ & -0.981 & $(0.891)$ & -1.042 & $(0.972)$ \\
\hline Manufacture of optical instruments and photographic equipment & 0.320 & $(0.110)^{\mathrm{a}}$ & 0.380 & $(0.094)^{\mathrm{a}}$ \\
\hline Manufacture of motor vehicles and their engines & 0.702 & $(0.646)$ & 0.668 & $(0.823)$ \\
\hline $\begin{array}{l}\text { Manufacture of bodies (coachwork) for motor vehicles; } \\
\text { manufacture of trailers and semi-trailers }\end{array}$ & 0.643 & $(0.704)$ & 0.622 & $(0.736)$ \\
\hline $\begin{array}{l}\text { Manufacture of parts and accessories (auto parts) for motor } \\
\text { vehicles and their engines }\end{array}$ & -0.349 & $(0.388)$ & -0.406 & $(0.450)$ \\
\hline Building and repairing of ships and boats & -3.440 & $(3.111)$ & -3.409 & $(3.203)$ \\
\hline Manufacture of aircraft and spacecraft & 0.212 & $(0.412)$ & -0.272 & $(0.318)$ \\
\hline Manufacture of other transport equipment n.p.c. & 0.357 & $(0.261)$ & 0.274 & $(0.301)$ \\
\hline Manufacture of furniture & 0.338 & $(0.396)$ & 0.360 & $(0.408)$ \\
\hline Manufacturing n.p.c. & -0.825 & $(0.318)^{\mathrm{a}}$ & -0.809 & $(0.330)^{\mathrm{a}}$ \\
\hline _cons & 1.812 & $(0.425)^{\mathrm{a}}$ & 4.344 & $(1.618)^{\mathrm{a}}$ \\
\hline Number of observations & 2906 & & 2906 & \\
\hline Observations per group (average) & 7.210 & & 7.210 & \\
\hline Sargan ( $p$-value) & 0.074 & & 0.144 & \\
\hline c1 ( $p$-value) & 0.000 & & 0.000 & \\
\hline c2 ( $p$-value) & 0.096 & & 0.133 & \\
\hline
\end{tabular}

Source: prepared by the authors.

${ }^{\mathrm{a}} \mathrm{p}<0.01$.

${ }^{\mathrm{b}} \mathrm{p}<0.05$.

${ }^{\mathrm{c}} \mathrm{p}<0.1$.

Note: standard errors in parentheses. Sargan test for overidentifying restrictions. c1 and c2 tests for first and second order correlation in first-differenced residuals.

n.p.c.: not previously classified. 
Colombia: estimation results for equation (4) for the sectors significantly affected by the variable

\begin{tabular}{|c|c|c|c|c|}
\hline \multirow{2}{*}{$q_{t} D_{s}$} & \multicolumn{2}{|c|}{ (1) } & \multicolumn{2}{|c|}{ (2) } \\
\hline & Coefficient & Standard error & Coefficient & Standard error \\
\hline $\begin{array}{l}\text { Manufacture of television and radio receivers, sound or image } \\
\text { recording or reproducing apparatus, and associated goods }\end{array}$ & -4.076 & $(0.280)^{\mathrm{a}}$ & -3.831 & $(0.323)^{\mathrm{a}}$ \\
\hline $\begin{array}{l}\text { Manufacture of veneer sheets, manufacture of plywood, } \\
\text { laminboard, particle board and other panels and boards }\end{array}$ & -3.681 & $(0.214)^{\mathrm{a}}$ & -3.810 & $(0.184)^{\mathrm{a}}$ \\
\hline Finishing of textiles not produced in the same production unit & -1.789 & $(0.625)^{\mathrm{a}}$ & -1.916 & $(0.703)^{\mathrm{a}}$ \\
\hline Manufacture of rubber products & -1.326 & $(0.389)^{\mathrm{a}}$ & -1.352 & $(0.332)^{\mathrm{a}}$ \\
\hline Manufacture of non-metallic mineral products n.p.c. & -1.278 & $(0.308)^{\mathrm{a}}$ & -1.227 & $(0.315)^{\mathrm{a}}$ \\
\hline Manufacture of wooden containers & -1.258 & $(0.364)^{\mathrm{a}}$ & -1.335 & $(0.287)^{\mathrm{a}}$ \\
\hline Sugar mills and refineries & -1.151 & $(0.401)^{\mathrm{a}}$ & -1.203 & $(0.412)^{\mathrm{a}}$ \\
\hline Manufacture of dairy products & -1.142 & $(0.482)^{\mathrm{b}}$ & -0.984 & $(0.482)^{\mathrm{b}}$ \\
\hline Manufacture of refined petroleum products & -1.137 & $(0.542)^{\mathrm{b}}$ & -1.125 & $(0.519)^{\mathrm{b}}$ \\
\hline Manufacture of other chemical products & -1.033 & $(0.507)^{\mathrm{b}}$ & -0.962 & $(0.533)^{\mathrm{c}}$ \\
\hline Manufacture of electric lamps and lighting equipment & -1.033 & $(0.310)^{\mathrm{a}}$ & -1.036 & $(0.340)^{\mathrm{a}}$ \\
\hline $\begin{array}{l}\text { Manufacture of paper, cardboard and paper } \\
\text { and cardboard products }\end{array}$ & -0.912 & $(0.385)^{\mathrm{b}}$ & -0.850 & $(0.398)^{\mathrm{b}}$ \\
\hline Manufacturing n.p.c. & -0.825 & $(0.318)^{\mathrm{a}}$ & -0.809 & $(0.330)^{\mathrm{a}}$ \\
\hline Weaving of textiles & -0.822 & $(0.329)^{\mathrm{b}}$ & -0.839 & $(0.343)^{\mathrm{b}}$ \\
\hline $\begin{array}{l}\text { Manufacture of structural metal products, tanks, reservoirs and } \\
\text { steam generators }\end{array}$ & -0.770 & $(0.378)^{\mathrm{b}}$ & -0.819 & $(0.413)^{\mathrm{b}}$ \\
\hline Manufacture of basic iron and steel & -0.726 & $(0.335)^{\mathrm{b}}$ & -0.791 & $(0.325)^{\mathrm{b}}$ \\
\hline Printing & -0.582 & $(0.257)^{\mathrm{b}}$ & -0.675 & $(0.306)^{\mathrm{b}}$ \\
\hline Manufacture of footwear & -0.538 & $(0.195)^{\mathrm{a}}$ & -0.545 & $(0.226)^{\mathrm{b}}$ \\
\hline Manufacture of optical instruments and photographic equipment & 0.320 & $(0.110)^{\mathrm{a}}$ & 0.380 & $(0.094)^{\mathrm{a}}$ \\
\hline Publishing & 0.679 & $(0.359)^{\mathrm{c}}$ & 0.717 & $(0.381)^{\mathrm{c}}$ \\
\hline Manufacture of insulated wire and cable & 2.953 & $(0.148)^{\mathrm{a}}$ & 3.013 & $(0.153)^{\mathrm{a}}$ \\
\hline
\end{tabular}

Source: prepared by the authors.

${ }^{\mathrm{a}} \mathrm{p}<0.01$

$\mathrm{b} \mathrm{p}<0.05$.

${ }^{\mathrm{c}} \mathrm{p}<0.1$.

Note: we present in this table the significantly estimated results for the parameter $\beta_{2}$ in equation (3). Standard errors in parentheses. The shaded rows correspond to the sectors that have been affected positively by the real appreciation of the Colombian peso.

n.p.c.: not previously classified.

TABLE A.3.4

Colombia: share of value added, employees and firms of the sectors that saw a significant impact on value added as a result of real exchange rate appreciation

Sectors significantly impacted by real exchange rate appreciation
Percentages of total

Value added Number of employees Number of firms

\begin{tabular}{lrrr}
\hline Negative effect & 52.7 & 38.7 & 35.9 \\
Positive effect & 4.0 & 2.1 & 5.7 \\
\hline
\end{tabular}

Source: prepared by the authors. 


\section{Bibliography}

Acosta, P., E. Lartey and F. Mandelman (2009), "Remittances and the Dutch disease", Journal of International Economics, vol. 79, No. 1, Amsterdam, Elsevier.

Algieri, B. (2011), "The Dutch disease: evidences from Russia", Economic Change and Restructuring, vol. 44, No. 3, Springer.

Anderson, T. and C. Hsiao (1981), "Estimation of dynamic models with error components", Journal of the American Statistical Association, vol. 76, No. 375, Alexandria, American Statistical Association.

Arellano, C. and others (2005), "The dynamic implications of foreign aid and its variability", IMF Working Papers, No. 05/119, Washington, D.C., International Monetary Fund, June.

Arellano, M. and O. Bover (1995), "Another look at the instrumental variable estimation of error-component models", Journal of Econometrics, vol. 68, No. 1, Amsterdam, Elsevier.

Arellano, M. and S. Bond (1991), "Some tests of specification for panel data: Monte Carlo evidence and an application to employment equations", Review of Economic Studies, vol. 58, No. 2, Wiley Blackwell.

Berg, A., J. Ostry and J. Zettelmeyer (2012), "What makes growth sustained?", Journal of Development Economics, vol. 98, No. 2, Amsterdam, Elsevier.

Berman, N., P. Martin and T. Mayer (2012), "How do different exporters react to exchange rate changes?", The Quarterly Journal of Economics, vol. 127, No. 1, Oxford University Press.

Beverellli, C., S. Dell'Erba and N. Rocha (2011), "Dutch disease revisited. Oil discoveries and movements of the real exchange rate when manufacturing is resource-intensive", International Economics and Economic Policy, vol. 8, No. 2, Springer.

Buiter, W.H. and D.D. Purvis (1983), "Oil, disinflation, and export competitiveness: A model of the Dutch Disease", Economic Interdependence and Flexible Exchange Rates, J.S. Bhandari and B.H. Putnam (eds.), Cambridge, Massachusetts, The MIT Press.

Burgess, S. and M. Knetter (1998), "An international comparison of employment adjustment to exchange rate fluctuations", Review of International Economics, vol. 6, No. 1, Wiley Blackwell.

Campa, J. and L. Goldberg (2001), "Employment versus wage adjustment and the Us dollar", Review of Economics and Statistics, vol. 83, No. 3, The MIT Press.

(1995), "Investment in manufacturing, exchange rates and external exposure", Journal of International Economics, vol. 38, No. 3-4, Amsterdam, Elsevier.

Campbell, J.R. and B. Lapham (2004), "Real exchange rate fluctuations and the dynamics of retail trade industries on the U.S.-Canada border", The American Economic Review, vol. 94, No. 4, Nashville, Tennessee, American Economic Association.

Carranza, J. and S. Moreno (2013), "Tamaño y estructura vertical de la cadena de producción industrial colombiana desde 1990", Borradores de Economía, No. 751, Bogota, Bank of the Republic.

Clavijo, S. (1990), "Productividad laboral, multifactorial y la tasa de cambio real en Colombia", Ensayos sobre politica económica, Bogota, Bank of the Republic.

Corden, W.M. (1984), "Booming sector and Dutch disease economics: Survey and consolidation", Oxford Economic Papers, vol. 36, No. 3, Oxford, Oxford University Press.
Corden, W.M. and J.P. Neary (1982), "Booming sector and deindustrialisation in a small open economy", Economic Journal, vol. 92, No. 368, Hoboken, John Wiley \& Sons.

Dinero (2011), 18 August [online] http://www.dinero.com/pais/articulo/ santos-reune-empresarios-inicio-su-visita-argentina/133589.

Echavarría, J.J. and M.A. Arbeláez (2003), "Tasa de cambio y crecimiento económico en Colombia durante la última década", Borradores de Economía, No. 338, Bogota, Bank of the Republic.

Echavarría, J.J. and M. Villamizar (2006), "El proceso colombiano de desindustrialización”, Borradores de Economía, No. 361, Bogota, Bank of the Republic.

Egert, B. and C. Leonard (2008), "Dutch disease scare in Kazakhstan: is it real?", Open Economies Review, vol. 19, No. 2, Springer.

Ekholm, K., A. Moxnes and K. Ulltveit-Moe (2012), "Manufacturing restructuring and the role of real exchange rate shocks", Journal of International Economics, vol. 86, No. 1, Amsterdam, Elsevier.

Goldberg, L.S. (1993), "Exchange rates and investment in United States industry", The Review of Economics and Statistics, vol. 75, No. 4, Cambridge, Massachusetts, The MIT Press.

Goldberg, L., J. Tracy and S.R. Aaronson (1999), "Exchange rates and employment instability: evidence from matched CPS data", American Economic Review, vol. 2, No. 89, Nasvhille, Tennessee, American Economic Association.

Guha, P. (2013), "Macroeconomic effects of international remittances: the case of developing economies", Economic Modelling, vol. 33, Amsterdam, Elsevier.

Lartey, E.K.K. (2011), "Financial openness and the Dutch disease", Review of Development Economics, vol. 15, No. 3, Wiley Blackwell.

Magud, N. and S. Sosa (2010), "When and why worry about real exchange rate appreciation? The misssing link between Dutch disease and growth", IMF Working Papers, No. 10/271, Washington, D.C., International Monetary Fund, December.

Poncela, P., E. Senra and L. Sierra (2012), "Is the boost in oil prices affecting the appreciation of real exchange rate?: empirical evidence of 'Dutch disease' in Colombia”, Documentos de Trabajo, No. 694, Madrid, Fundación de las Cajas de Ahorros (FUnCAs).

Prati, A. and T. Tressel (2005), "Aid volatility and Dutch disease: is there a role for macroeconomic policies?", IMF Working Papers, No. 06/145, Washington, D.C., International Monetary Fund, March.

Rajan, R.G. and A. Subramanian (2011), "Aid, Dutch disease, and manufacturing growth", Journal of Development Economics, vol. 94, No. 1, Amsterdam, Elsevier.

Rhenals, R. and J. Saldarriaga (2007), "Tasa de cambio real y crecimiento económico en Colombia, 1995-2006: Una exploración inicial", Perfil de Coyuntura Económica, Medellin, Antioquia, University of Antioquia.

Rodrik, D. (2008), "The real exchange rate and economic growth", Brookings Papers on Economic Activity, vol. 39, No. 2, Washington, D.C., The Brookings Institution.

Salter, W. (1959), "Internal and external balance: the role of price and expenditure effects", Economic Record, vol. 35, No. 71, Wiley.

Swan, T. (1960), "Economic control in a dependent economy", Economic Record, vol. 36, No. 73, Wiley. 